\title{
Yatırımcıların Özellikleri İle Hisse Senedi Piyasalarındaki Anomali Algısı Arasındaki iliş̧ki: Bireysel Yatırımcılar Üzerine Bir Araştırma
}

\author{
The Relation between Characteristics of Investors and Perception of Anomalies in Stock \\ Market: A Study on Individual Investors
}

İstemi ÇÖMLEKÇi' ${ }^{1}$, Mehmet Akif ÖNCÜ', Serap ÇAKIR ÇÖMLEKÇi๋ ${ }^{1}$

\section{ÖZET}

\begin{abstract}
Hisse senedi fiyatlarının belirli zaman ve dönemlerde diğer zamanlara göre farklı getiri sağlaması olarak ifade edilen anomaliler, etkin piyasalar hipotezi ile ters düşmektedir. Hisse senedi piyasalarında belirli dönemlerde, yüksek getiri sağlanması veya aşırı kayıplara katlanılması bireysel yatırımcıların anomali algılarını önemli kılmaktadır. Bu çalışmada Borsa İstanbul'da işlem yapan bireysel yatırımcıların anomali algısı ve anomali algıları ile yatıımcı özellikleri arasındaki ilişki sorgulanmaktadır. Borsa İstanbul'da hisse senedi alım/satımı yapmış tüm bireysel yatırımcılar araştırma evrenini oluşturmaktadır. Araştırmada örneklemeye başvurulmuş olup, kartopu örnekleme tercih edilmiştir. Araştırma sonucu bireysel yatııımcıların anomalileri, fiyat anomalisi, firma anomalisi, haftanın günü anomalisi ve gün içi anomalisi olarak algıladıkları tespit edilmiştir. Ayrıca yatırımcıların demografik özelliklerine ve yatırımcı özelliklerine göre anomali algılarında farklııklar olduğu sonucuna ulaşıımıştır.
\end{abstract}

Anahtar kelimeler: Etkin Piyasalar Hipotezi; Davranışsal Finans; Anomalilier; Yatırımcı Özellikleri

\section{GíRiş}

Etkin piyasalar hipotezi ile etkin bir piyasada hisse senedi fiyatlarının piyasadaki her türlü bilgiyi yansıttığı ve hiçbir yatırımcının ekstra bir kazanç elde etmesinin mümkün olmadığı belirtilmektedir (Fama, 1970:384) .

$\mathrm{Bu}$ hipotezi öne süren Eugene Fama piyasanın etkinliğini, yatırımcının geçmiş fiyat hareketlerini kullandığı zayıf form, geçmiş fiyatlara ek olarak kamuya açıklanan bilgilerin kullanıldığı yarı-güçlü form ve bunlara ek olarak özel kaynaklı bilgilerin kullanıldığı güçlü form bilgi girişlerine göre sınıflandırmaktadır (Karan, 2001:268-269). Ampirik araştırmalarda bu varsayımla çelişen bulgulara rastlanılmış olup, piyasaların etkin olmadığı, piyasa etkinliğinde sapmaların olduğu tespit edilmiştir. Hisse senedi fiyatlarındaki bu sapmalar anomali olarak ifade edilmektedir (Pompian, 2006: 8-9).

Anomali, teori ile uyuşmayan bir gözlem ya da re-

\begin{abstract}
Anomalies which referred as the stock prices provide different return than other times at certain periods collide with the efficient markets hypothesis. High returns or losses in this certain period make the individual invertors' perceptions important. In this study, anomalies perception of individual investors who traded in Istanbul Stock Exchange and the relationship between perceptions of anomalies and investor properties are questioning. The universe is formed from all individual investors who have done one or more trade in Borsa Istanbul. In the research sampling was applied and snowball sampling was preferred. At the end of the research, we determine that individual investors perceive the anomalies as price anomaly, firm anomaly, day of week anomaly and intraday anomaly. According to search result, perception of anomalies is differing by individual investors' demographic characteristics.
\end{abstract}

Keywords: Efficient Markets Hypothesis; Behavioral Finance; Anomalies; Investors characteristics

alitedir (Kahneman vd., 1991: 193). Etkin piyasalar hipotezindeki sapmaları bilimsel olarak açıklamak için uluslararası literatürde anomaliler çeşitlendirilmiştir. Piyasalarda görülen anomalileri dönemsel anomaliler, firma anomalileri ve fiyat anomalileri olarak incelemek mümkündür. Takvimsel/Mevsimsel olarak da ifade edilen dönemsel anomaliler, saatlik, günlük, haftalık, aylık, yıllık veya belirli bir dönem öncesi ya da sonrası şeklinde oluşmaktadır. Fiyat anomalileri ise piyasa etkinliğinden sapma durumunu ifade eden, aşırı ve düşük reaksiyon şeklinde ortaya çıkmaktadır. Firma anomalilerini ise firma büyüklüğü anomalisi ve inmal edilmiş firma anomalisi olarak çeşitlendirmek mümkündür. Bu anomaliler arasında takvimsel/dönemsel anomalilerin testi, piyasaların zayıf formda etkinliğini incelemede önemli bir araç olmuştur. Yarıgüçlü formda ise firma büyüklüğü etkisi, fiyat-kazanç oranı etkisi, düşük fiyat etkileri piyasanın etkinliğini ölçmede kullanılmaktadır (Barak ve Demireli, 2008: 207-211). 
Etkin piyasalar hipotezini kabul görmeyen davranışsal finans modelleri, sosyolojiden, psikolojiden ve antropolojiden gelen insan davranışı teorilerini benimsemekle birlikte, insanların davranışlarında tam rasyonel olmadığı ve anormalliklere insanların özelliklerinin sebep olduğu üzerine kuruludur (Shiller, 1998: 1-3). Yatırımcıların demografik özelliklerinin, psikolojik ön yargılarının, gelirinin, çalışma durumunun yatııım kararı üzerinde etkili olduğu bilimsel olarak kanıtlanmıştır.

Bu çalışmada, bireysel yatırımcıların hisse senedi piyasalarında görülen anomalilere ilişkin görüşlerinin hangi boyutlar altında toplandığını belirlenerek, yatırımcıların özellikleri ile anomali algısı arasındaki ilişki irdelenmiştir.

\section{LITERATÜR TARAMASI}

Anomaliler ve bireysel yatırımcıların finansal davranışları, finans literatürüne yeni bir boyut kazandırdığı için yerli ve yabancı akademisyenlerin ilgisini odağı olmuştur. Hisse senedi piyasalarında görülen anomaliler, incelenen dönem ve menkul kıymet piyasasına göre değişiklik göstermekle beraber genel olarak, dönemsel anomaliler, firma anomalileri ve fiyat anomalileri olarak üç başıık altında incelenmektedir.

\subsection{Dönemsel (Takvimsel / Mevsimsel) Anomaliler}

Menkul kıymetlerin herhangi bir dönemde normal zamanlara göre sürekli farklı performans göstermesi durumu genel olarak dönemsel anomali olarak ifade edilmektedir. Dönemsel anomaliler, gün anomalisi, ay anomalisi ve tatil anomalisi olarak sınıflandırılabilir (Barak, 2006:125).

\subsubsection{Gün Anomalileri}

Menkul kıymetin belirli günlerde ya da gün içinde diğer günlere ve saatlere göre farklı getirilerin elde edilip edilemeyeceğini araştıran gün anomalileri, finansal literatürde haftanın günleri anomalisi, hafta sonu anomalisi ve gün içi anomalisi olarak üç farklı şekilde ele alınmaktadır. Yapılan çalışmalarda genel olarak pazartesi günlerinin düşük getiri ile sonuçlandığı, en çok kazandıran günün ise Cuma günleri olduğu sonucuna ulaşılmıştır. Bu konuyla ilgili çalışma yapan ve günlük getiriler arasında farklılıklar olabileceğini ortaya koyan ilk kişi Fields (1931)'dir. Fields çalışmasında, hafta sonlarındaki belirsizlikten dolayı riskin artacağını, yatırımcıların ellerindeki hisse senetlerini satacaklarını varsaymış ve haftanın son işlem günü hisse senedi fiyatlarının düşme eğiliminde olacağını ileri sürmüştür. Fakat araştırma sonucunda tam tersi bir sonuca ulaşmıştır (Barak, 2006,126).

Cross (1973) tarafından yapılan çalışmada, New
York Borsası'nda hisse senedi getirilerinin Pazartesi günleri bir önceki işlem gününe nazaran düşüş gösterdiğini, Cuma günleri ise bir önceki güne göre önemli ölçüde yükseldiğini gözlemlemiştir.

S\&P 500 endeksini, 1953-1977 dönemi için kullanan French (1980), Rogalski (1984), Pazartesi ortalama getirilerinin negatif; Cuma ve Çarşamba günleri en yüksek olmak üzere, haftanın diğer günlerinin getirilerinin pozitif olduğunu saptamıştır.

Jaffe ve Westerfield (1985), 1962-1983 dönemi için Amerikan S\&P500, 1970-1983 dönemi için Japon Nikkei Dow, 1976-1983 dönemi için Kanada Toronto, 1950-1983 dönemi için İngiliz FTOSI ve Avustralya SAI Endekslerini haftanın günü anomalisi açısından incelemişlerdir. ABD, İngiltere ve Kanada'da en çok zarar ettiren gün pazartesi olarak, Japonya ve Avustralya'da salı günü olarak, en çok kazandıran gün olarak da Cuma gününü tespit etmişlerdir.

Wong ve diğ (1992), Singapur, Malezya, Hong Kong, Tayland ve Tayvan'da yaptıkları çalışmalarında Tayvan hariç tüm ülkelerde Pazartesi ve Salı günü getirilerinin negatif, Cuma günü getirilerin ise pozitif olduğu yönünde bulgulara ulaşmıştırlar. Agrawal ve Tandon (1994), 18 ülkeyi kapsayan çalışmasında benzer sonuçları elde ederken, Nawaz ve Mirza (2012) ise dönemsel anomalilerle ilgili literatür araştırmasında negatif pazartesi etkisini ve pozitif Cuma etkisini belirtmişlerdir.

Balbina ve Martins (2002), Portekiz piyasasında yaptıkları araştırmada hafta sonu etkisine rastlamışlardır. Bayar ve Kan (2002), 19 ülkeyi kapsayan çalışmasında, hem yerel para hem de dolar cinsinden Salı ve Çarşamba günleri düşük getirinin, Perşembe ve Cuma günleri ise yüksek getirinin olduğu bulgusuna ulaşmışlardır. Guo ve Wang (2007) Şangay Borsası'nda 1992-2006 dönemlerini kapsayan incelemelerinde, en düşük getirinin Salı günleri, en yüksek getirinin ise Cuma günleri gerçekleştiğini tespit etmişlerdir.

Haftanın günü etkisi üzerine Borsa İstanbul için yapılan çalışmalar incelendiğinde ise genel olarak $\mathrm{Pa}$ zartesi ve Salı günlerinin negatif getiri ile sona erdiği, Cuma günlerinin ise en fazla getiriyi sağlayan gün olduğu görülmektedir (Balaban, 1995; Bildik, 2000; Karan, 2001; Tunçel, 2008; Erdoğan ve Elmas, 2010).

\subsubsection{Ay Anomalileri}

Ay anomalileri, yılın herhangi bir ayında diğer aylara göre hisse senedi getirilerinin farklılık göstermesidir. Ay anomalileri Ocak ayı, ay içi, ay sonu ve yıl sonu etkisi başlı̆ı altında ele alınmaktadır. Yapılan araştırmalarda genellikle ocak ayında hisse senedi getirilerinin diğer aylara oranla yüksek olduğu tespit edilmiştir (Barak, 2008, 137). 
Rogalski (1984), Jaffe ve Westerfield (1985), Agrawal ve Tandon'un (1994), Balbina ve Martins (2002), Guo ve Wang (2007) yaptıkları çalışmalarda özetle ocak ayında pozitif getiri bulgusuna ulaşmışlardır.

Aylara ilişkin anomalilerle ilgili Türkiye'de yapılan çalışmalarda ise ocak ayı anomalisinin varlığı tespit edilmiştir (Bildik, 2000; Karan, 2001; Ergün, 2009; Erdoğan ve Elmas, 2010; Ege ve diğ., 2012). Diğer taraftan Abdioğlu ve Değirmenci (2013) 2002-2013 ve alt dönemler itibariyle ocak ayındaki getirilerin kriz dönemi hariç diğer aylardaki getirilerden farklı olmadığı sonucuna ulaşmışlar ve yapılan testlerden ampirik bulgularda ay sonu ve yıl sonu etkisinin olmadığı bulgusunu elde etmişlerdir.

\subsubsection{Tatil Anomalileri}

Tatillere ilişkin anomalilerde, resmi, dini ve hafta sonu tatillerinde hisse senedi getirilerinin tatil öncesi ve sonrasında farklılık arz ettiği ifade edilmektedir (Ergün, 2009: 29). Roll (1983) ve Lakonishok ve Smidt (1984) Aralık ayının son günü ile yılbaşı tatili öncesi getirilerinin olağanüstü bir şekilde yükseldiğini tespit etmişlerdir (Akt: Özmen, 1997: 42).

Özmen (1997), tatil anomalileri üzerine yaptığı çaIışmada Borsa İstanbul'un 1988-1996 döneminde resmi tatil öncesi getirilerin tatil sonrası getirilere göre daha yüksek olduğu bulgusuna ulaşmıştır. Diğer taraftan Abdioğlu ve Değirmenci (2013) ise 2002-2013 ve alt dönemler itibariyle IMKB 100 endeksinde tatil öncesi ve tatil sonrasında getiri bakımından bir farklılık olmadığını tespit emiştir.

\subsection{Firma Anomalileri}

Firma anomalileri, firmaların büyüklüğüne ve piyasalardaki işlem sayılarına göre hisse senedi getirilerinin farklılaştığı durumlarda oluşmaktadır. Firma büyüklüğü anomalisi ve ihmal edilmiş firma anomalisi olarak çeşitlendirilebilir (Ergün, 2009: 30).

Firma büyüklüğü anomalisi, küçük Pazar değerine sahip hisse senetlerinin daha çok getiri sağlaması durumunda ortaya çıkmaktadır. Reinganum (1982), çalışmasında küçük Pazar değerine sahip hisse senetlerinden oluşan portföylerin getirilerinin diğerlerinden daha yüksek olduğunu tespit etmiştir (Ergün, 2009, 31). Demir ve diğ. (1996), Borsa İstanbul'da 19901996 arasındaki verilerle firma büyüklüğü etkisini test etmiş olup çalışma sonucunda piyasa değeri küçük olan ilk iki portföyün piyasa değeri yüksek olan son iki portföye oranla daha fazla getiri sağladığı gözlemlemiştir.

İhmal edilmiş firma anomalisi ise uzmanlar ve yatırımcılar tarafından daha az tavsiye edilen ve daha az işlem gören hisse senetlerinin daha çok kazandırması durumu olarak ifade edilmektedir. Arbel ve Strabel (1982) ile Merton (1987), yaptıkları çalışmada ihmal edilmiş firmaların hisse senetlerinin daha çok kazandırabileceklerini belirtmişlerdir (Akt: Taşkın, 2006,35). Karan (2000) tarafından Türkiye'de 1996-1998 yıllarındaki Borsa İstanbul verileri kullanılarak yapılan çalışmada ihmal edilmiş hisse senetlerinin, popüler hisse senetlerine göre daha fazla getiri sağladığı sonucuna ulaşmıştır.

\subsection{Fiyat Anomalileri}

Fiyat anomalileri, eksik reaksiyon ve aşırı reaksiyon anomalisi olmak üzere iki başlık altında sınıflandırılabilir.

De Bondt ve Thale'e göre (1985), Fiyat/kazanç oranı düşük olan hisse senetleri, fiyat/kazanç oranı yüksek olan hisse senetlerine göre daha yüksek getiri sağlamaktadırlar. Bu durum düşük fiyat/kazanç oranına sahip hisseleri elinde bulunduran yatırımcıların, ardı ardına gelen birkaç olumsuz haberden sonra elde edebilecekleri getirilere ilişkin karamsarlığa düşmeleri sonucu, hisse senetlerinin eksik değerlenmesinden kaynaklanmaktadır. Geçmiş üç veya beş yılda yatırımcılarına kaybettiren hisse senetleri, izleyen dönemlerde geçmiş üç veya beş yılda yatırımcılarına kazandıran hisse senetlerine göre daha iyi performans göstermektedirler. Öte yandan Jegadeesh ve Titman (1993) ise geçmiş dönemde daha yüksek getiri sağlayan hisse senetlerinin, geçmiş dönemde kaybettiren hisse senetlerine göre daha yüksek getiri sağlamadığı görüşünü savunmaktadırlar. Madiha ve diğ. (2011)'e göre ise aşıı tepki etkisi kaybeden hisselerde kazanan hisselere göre daha yüksek olduğu için, kaybeden hisseler kazanan hisselere göre daha fazla tepki vermektedirler ve gelecek dönemlerde daha fazla getiri sağlayacaktır.

Barak (2008) 1992-2004 yılları arasında IMKB'de işlem gören 80 adet hisse senedine ilişkin bilgileri kullandığı çalışmasında aşııı tepki anomalisini test etmiş, IMKB'de yatııımcıların, uzun dönemde, kazanan/ kaybeden portföy stratejileri ile piyasa üzerinde getiri elde edebilecekleri sonucuna ulaşmıştır.

\section{ARAŞTIRMANIN YÖNTEMi}

Bu araştırmanın temel amacl; bireysel yatırımcıların hisse senedi piyasalarında görülen anomalilere ilişkin görüşlerinin hangi boyutlar altında toplandığını belirlemek ve yatırımcıların özellikleri ile anomali algıları arasındaki ilişkiyi incelemektir. Günümüzde yaşanan teknolojik gelişmeler sonucu hisse senedi piyasalarında işlem yapmanın kolaylaşması nedeni ile araştırma evreni belirlenirken coğrafi bir sınırlamaya gidilmemiştir. Bu doğrultuda Borsa İstanbul'da hisse senedi alım/satımı yapmış tüm bireysel yatırımcılar araştırma evrenini oluşturmaktadır. Borsa İstanbul'da 
Aralık 2013 itibari ile 1.095.161 adet bireysel yatırımcı bulunmaktadır (TÜYiD ve MKK, 2014). Araştırma evrenin tamamına ulaşmanın zaman ve maliyet açısından güç olmasının yanı sıra, yatııımcı bilgilerinin gizliliği nedeni ile imkânsız hale gelmektedir. Bu nedenle araştırmada örneklemeye başvurulmuş olup, kartopu örnekleme tercih edilmiştir. Altunışık ve diğ. (2010) 100.000 ve üzeri evren büyüklüğü için gerekli olan örneklem büyüklüğü 384 olarak belirtmektedirler. Bu kapsamda örneklem büyüklüğü 384 olarak belirlenmiştir.

Araştırmada veri toplama aracı olarak anket kullanılmıştır. Üç bölümden oluşan anket formunun birinci bölümünde yanıtlayıcıların demografik özelliklerini, ikinci bölümde ise yatırımcı özelliklerini belirlemeye yönelik sorular yer almaktadır. Son bölümde ise yatırımcıların hisse senedi piyasalarında var olan anomalilere ilişkin algılarını ölçmeye yönelik Likert ölçeğinde hazırlanmış ifadelere yer verilmiştir. 5'li Likert ölçeğine göre yapılandırılmış ifadeler 1. Kesinlikle katılmıyorum 5. Kesinlikle katılıyorum seçeneğine doğru sıralanmıştır. Oluşturulan anket formunun geçerlilik ve güvenirliğinin sağlanması için bireysel yatırımcılar konusunda uzman iki yatırım danışmanının ve iki akademisyenin görüşleri alınarak, gerekli düzenlemeler yapılmış ve anket formuna son hali verilmiştir. Anket uygulaması 02.01.2014 - 31.03.2014 tarihleri arasında online anket formu oluşturularak gerçekleştirilmiştir.
Bu dönemde yeterli anket sayısına ulaşılmadığı için 31.04.2014 tarihine kadar anket uygulamasına yüz yüze görüşme yöntemi ile devam edilmiştir. Toplam 488 adet anket formu elde edilmiş olup bu anket formlarından 32 tanesi eksik doldurulduğu için çalışma kapsamında değerlendirilmeye alınmamıştır. Araştırmanın bulguları 456 adet bireysel yatırımcının görüşleri dikkate alınarak elde edilmiştir.

Anket uygulaması sonucunda elde edilen veriler SPSS 15.0 paket programı kullanılarak analiz yapılmıştır. Analizlere öncelikle verilerin güvenirliliğinin incelenmesiyle başlanmıştır. Uygulanan anketin sonucu elde edilen verilerin güvenilirliği (Chronbach Alpha) 0,84 olarak hesaplanmıştır. Araştırmadan elde edilen verilerin genel olarak güvenilir olduğunun söylenebilmesi için güvenilirlik testi sonuçlarının 0,7 düzeyinin üzerinde gerçekleşmesi gerekmektedir (Nunnally, 1967).

\section{BULGULAR}

Bireysel yatırımcıların demografik özelliklerinin belirlemesi için frekans analizi uygulanmıştır. Anomali algısına etki eden boyutları belirlemek için faktör analizi yapılmış ve faktör analizi sonucu ortaya çıkan faktörler arası korelasyon incelenmiştir. Katılımcıların demografik özelliklerine ilişkin dağı̆ım Tablo 1'de verilmiştir.

Tablo 1. Katılımcıların demografik ve yatıımcı özelliklerine ilişkin dağılım

\begin{tabular}{|c|c|c|c|c|c|c|c|}
\hline & & $\begin{array}{c}\text { Görülme } \\
\text { Sıklığı }\end{array}$ & Yüzde \% & & & $\begin{array}{l}\text { Görülme } \\
\text { Sıklığı }\end{array}$ & Yüzde \% \\
\hline \multirow{2}{*}{ 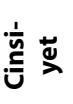 } & Erkek & 297 & 65,1 & \multirow{5}{*}{ 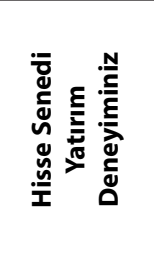 } & 1 yıldan az & 76 & 16,6 \\
\hline & Kadın & 159 & 34,9 & & $1-3$ yıl & 90 & 19,7 \\
\hline \multirow{3}{*}{ 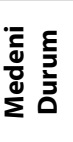 } & Bekar & 159 & 34,9 & & 4-6 yıl & 87 & 19,1 \\
\hline & Evli & 279 & 61,2 & & 7-10 yıl & 85 & 18,6 \\
\hline & Diğer & 18 & 3,9 & & 10 yıl ve üzeri & 118 & 25,9 \\
\hline \multirow{5}{*}{ 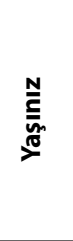 } & $18-24$ & 34 & 7,5 & \multirow{5}{*}{ 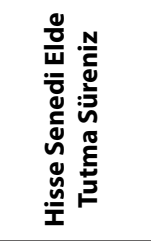 } & 0-3 ay & 155 & 34,0 \\
\hline & $25-34$ & 171 & 37,5 & & 4-6 ay & 144 & 31,6 \\
\hline & $35-44$ & 148 & 32,5 & & 7-11 ay & 56 & 12,3 \\
\hline & $45-54$ & 68 & 14,9 & & 1-3 yıl & 50 & 11,0 \\
\hline & 55 yaş ve üstü & 35 & 7,7 & & 4 yıl ve üzeri & 23 & 10,9 \\
\hline \multirow{4}{*}{ 旋 } & İlköğretim & 11 & 2,4 & \multirow{4}{*}{ 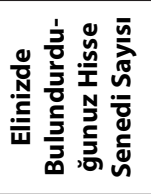 } & $1-3$ adet & 214 & 47,0 \\
\hline & Lise & 76 & 16,7 & & 4-6 adet & 120 & 26,3 \\
\hline & Lisans & 260 & 57,0 & & 7-10 adet & 70 & 15,4 \\
\hline & Lisansüstü & 109 & 23,9 & & 11- ve üzeri & 51 & 11,2 \\
\hline \multirow{6}{*}{ 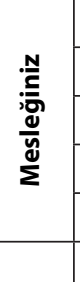 } & Ücretli çalışan (özel sektör) & 216 & 47,4 & \multirow{6}{*}{ 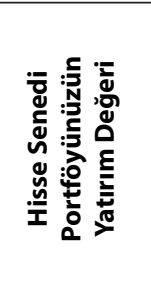 } & 1000 TL ve altı & 60 & 13,1 \\
\hline & Ücretli (Kamu) & 125 & 27,4 & & $1.001-5.000 \mathrm{TL}$ arası & 113 & 24,8 \\
\hline & Serbest Meslek & 43 & 9,4 & & 5.001-10.000 TL arası & 66 & 14,5 \\
\hline & İşyeri sahibi & 25 & 5,5 & & 10.001-50.000 TL arası & 114 & 25,0 \\
\hline & Diğer & 47 & 10,4 & & 50.001-100.000 TL arası & 74 & 16,2 \\
\hline & Toplam & 456 & 100,0 & & 100.001 TL ve üzeri & 29 & 6,4 \\
\hline
\end{tabular}


Tablo 1'e göre katılımcıların \%65,1'i erkek, \%34,9"u kadındır. Medeni durumuna göre katılımclların \%61,2'si evlilerden oluşmaktadır. Yaş gruplarına göre dağılıma bakıldığında, 25-34 yaş grubu ile 35-44 yaş grubu, toplam katılımcıların \%70'ini oluşturmaktadır. Araştırma sorularını yanıtlayan 369 katılımcı $(\% 80,9)$ lisans ve lisansüstü eğitime sahiptir. Katılımcıların \%47,4'ü özel sektörde ücretli çalışanlardan, $\% 27,4$ 'ü ise kamuda ücretli çalışanlardan oluşmaktadır. Yanıtlayıcıların hisse senedi deneyim süresine bakıldığında, \%16,6'sının 1 yıldan az, \%19,7'sinin 1-3 yıl arası, \%19,17'inin 4-6 yıl arası, \%18,6'sının 7-10 yıl arası, \%25,9'ununu ise 10 yıl ve üzeri deneyime sahip olduğu görülmektedir. Anket çalışmasına katılanların $\% 65,6$ 'sı hisse senetlerini 6 ayda daha kısa süre içinde satmakta, \%73,3'ü ise 6 adetten fazla hisse senedi bulundurmamaktadır. Son olarak katılımcıların hisse senedi portföy yatırım değeri irdelendiğinde 60 kişinin $(\% 13,1) " 1.000$ ve altı, 113 kişinin $(\% 24,8) " 1.001$ "5.000, 66 kişinin (\% 14,5) "5.001-"10.000, 114 kişinin (\% 25,0) "10.001-"50.000, 74 kişinin (\% 16,2) "50.001"100.000, 29 kişinin ise $(\% 6,4) " 100.001$ ve üzeri hisse senedi yatırımına sahip olduğu görülmektedir.

1.4. Hisse Senedi Piyasalarındaki Anomali Algısına İlişkin Faktör Analizi

Aralarında ilişki olduğu düşünülen çok sayıdaki değişkeni, az sayıdaki boyutlara indirgeyen faktör analizinin temel amacl, değişkenleri arasındaki ilişkilerin anlaşılmasını ve yorumlanmasını kolaylaştırmaktır (Altunışık ve diğ., 2007). Araştırma kapsamında yatırımcılarının anomali algısına etkilediği tahmin edilen önermeler, faktör analizlerine tabii tutulmuş ve hisse senedi piyasalarında görülen anomali türlerine ilişkin alt boyutlar belirlenmeye çalışılmıştır. Bir veri setinin faktör analizine uygunluğu için Kaiser-MeyerOlkin katsayısının 0,60'dan yüksek çıkması ve Barlett küresellik testinin anlamlı olması gerekmektedir. (Büyüköztürk, 2011). Bu bağlamda araştırma kapsamında elde edilen verilerin faktör analizi için gerekli istatistiki özelliklere sahip olduğu söylenebilir ( $K M O=0,852$, ve Barlett testi $p<0,05)$. Faktör analizi sonucu elde edilen bulgular Tablo 2'de sunulmaktadır.
Tablo 2 incelendiğinde yapılan açıklayıcı faktör analizi sonucu, hisse senedi piyasalarında görülen anomalileri ölçen toplam 15 maddenin, öz değeri 1'den büyük 4 boyutla açıklandığı görülmektedir. Toplam varyansın \%64,63'ü bu 4 boyutla açıklanmaktadır. Birinci faktör toplam varyansın \%23,009'unu, ikinci faktör \%17.474'ünü, üçüncü faktör \%15,693'ünü ve son faktör ise \%8,463'ünü açıklamaktadır. Buna göre analizde ortaya çıkan 4 faktörün birlikte toplam varyansın büyük çoğunluğunu açıkladığı söylenebilir. Faktör analizi sonucu ortaya çıkan 4 faktörden birinci ve ikinci faktörler 5'er maddeden, üçüncü faktör üç maddeden ve son faktör ise iki maddeden oluşmaktadır. Faktör yükleri ortalamaları ise sırasıyla 0,734, $0,662,0,808$ ve 0,716 olarak gerçekleşmiştir.

Faktörlerdeki maddelerin içerikleri dikkate alınarak isimlendirme yapıldığında birinci faktörde yer alan maddelerin Firma Anomalisi ile ilgili olduğu görülmektedir. Bununla beraber "Geçmiş 5 yıl boyunca en çok kazandıran hisse senetleri takip eden 5 yıllık dönemde diğer hisse senetlerine oranla daha az kazandırabilir." ve "Geçmiş 5 yıl boyunca en çok kaybettiren hisse senetleri takip eden 5 yıllık dönemde diğer hisse senetlerine oranla daha az kaybettirebilir." gibi uzun dönemli fiyat hareketleri olarak ifade edilebilecek ve literatürde fiyat anomalisi olarak ele alınan önermelerin firma anomalisi olarak algılandığı tespit edilmiştir. Bu durumun uzun dönemli fiyat değişimlerinin hisse senedi yatırımcıları tarafından firma ile özdeşleşmiş olarak algılanmasından kaynaklandığı düşünülmektedir. İkinci faktörde yer alan maddelerin Fiyat Anomalileri ile ilgili olduğu, literatürde takvim anomalisi olarak ele alınan ay sonu ve ocak ayı anomalisinin de bu faktör altında yer aldığı görülmektedir. Literatürde takvim anomalisi altında incelenen Haftanın Günü ve Gün için Anomalilerine ilişsin önermelerin ise üçüncü ve dördüncü faktörler altında toplandığı tespit edilmiştir. 
Tablo 2. : Hisse Senedi Piyasalarındaki Anomali Algısına Illişkin Faktör Analizi - Dönüştürülmüş Bileşenler Matrisi

\begin{tabular}{|c|c|c|c|c|c|}
\hline & & 1 & 2 & 3 & 4 \\
\hline \multirow{5}{*}{ 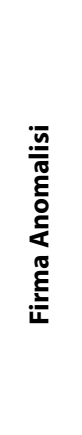 } & $\begin{array}{l}\text { Geçmiş } 5 \text { yıl boyunca en çok kazandıran hisse senetleri takip eden } 5 \\
\text { yıllık dönemde diğer hisse senetlerine oranla daha az kazandırabilir. }\end{array}$ &, 767 & & & \\
\hline & $\begin{array}{l}\text { Geçmiş } 5 \text { yıl boyunca en çok kaybettiren hisse senetleri takip eden } 5 \\
\text { yıllık dönemde diğer hisse senetlerine oranla daha az kaybettirebilir. }\end{array}$ & ,747 & & & \\
\hline & $\begin{array}{l}\text { Piyasa değerinin defter değerine oranı küçük olan firma hisse senetleri } \\
\text { büyük olanlara göre daha yüksek getiri sağlayabilir. }\end{array}$ &, 732 & & & \\
\hline & $\begin{array}{l}\text { Piyasa fiyatının hisse başına kazanca oranı yüksek olan hisse senedinin } \\
\text { düşük olan hisse senedine göre daha az getiri söz konusu olabilir. }\end{array}$ &, 715 & & & \\
\hline & $\begin{array}{l}\text { İşlem sayısı daha az olan hisse senetleri daha fazla olanlara göre daha } \\
\text { yüksek getiri sağlayabilir. }\end{array}$ & ,710 & & & \\
\hline \multirow{5}{*}{ 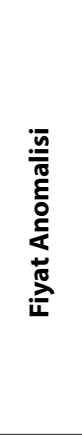 } & $\begin{array}{l}\text { Kısa vadede kazanan hisse senetleri alınarak ve kaybeden hisse } \\
\text { senetleri satılarak yüksek getiri elde edilebilir. }\end{array}$ & & ,702 & & \\
\hline & $\begin{array}{l}\text { Düşük fiyatlı hisse senetleri yüksek fiyatlı hisse senetlerine göre daha } \\
\text { yüksek getiri sağlayabilir. }\end{array}$ & & ,681 & & \\
\hline & $\begin{array}{l}\text { Hisse senedi alım satım işlemlerinde ocak aylarında yılın diğer aylarına } \\
\text { oranla göre daha yüksek getiri sağlanabilir. }\end{array}$ & &, 674 & & \\
\hline & $\begin{array}{l}\text { Orta ve uzun vadede kaybeden hisse senetleri alarak ve kazanan hisse } \\
\text { senetlerini satarak daha yüksek getiri elde edilebilir. }\end{array}$ & & 637 & & \\
\hline & $\begin{array}{l}\text { Hisse senedi alım satım işlemlerinde ay sonlarında ayın diğer zaman } \\
\text { dilimlerine göre daha yüksek getiri sağlanabilir. }\end{array}$ & & 619 & & \\
\hline \multirow{3}{*}{ 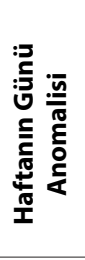 } & $\begin{array}{l}\text { Hisse senedi alım satım işlemlerinde Pazartesi günlerinde diğer } \\
\text { günlere göre daha düşük getiri söz konusudur. }\end{array}$ & & &, 835 & \\
\hline & $\begin{array}{l}\text { Hisse senedi alım satım işlemlerinde Cuma günleri diğer günlere göre } \\
\text { daha yüksek getiri sağlanabilir. }\end{array}$ & & & 807 & \\
\hline & $\begin{array}{l}\text { Hisse senedi alım satım işlemlerinde haftanın bazı günlerinde diğer } \\
\text { günlere göre daha yüksek getiri sağlanabilir. }\end{array}$ & & & ,783 & \\
\hline \multirow{6}{*}{ 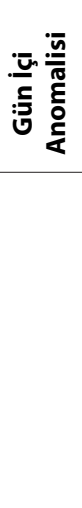 } & $\begin{array}{l}\text { Hisse senedi alım satım işlemlerinde seansın son } 30 \text { dakikasında diğer } \\
\text { zaman dilimlerine göre daha yüksek getiri sağlanabilir. }\end{array}$ & & & & 848 \\
\hline & $\begin{array}{l}\text { Hisse senedi alım satım işlemlerinde seansın son } 1 \text { dakikasında diğer } \\
\text { zaman dilimlerine göre daha yüksek getiri sağlanabilir. }\end{array}$ & & & &, 584 \\
\hline & Öz değerler & 5,508 & 2,104 & 1,048 & 1,035 \\
\hline & Faktör varyans yüzdeleri & 23,009 & 17,474 & 15,693 & 8,463 \\
\hline & Faktör Ortalamaları & 0,734 & 0,662 & 0,808 & 0,716 \\
\hline & Cronbach Alfa (a) Değerleri & 0,860 & 0,780 & 0,819 & 0,732 \\
\hline
\end{tabular}

Varimax Rotasyonlu Temel Bileşenler Faktör Analizi. Kaiser-Meyer-Olkin Örneklem Yeterliliği: ,852 Bartlett Küresellik Testi: $\mathrm{p}<0,05: \quad \mathrm{x}^{2}: 2889,853$, df: 105. Açıklanan Toplam Varyans: \% 64,638

Kullanılan Likert Ölçeği: 1: Kesinlikle katılmıyorum........ 5: Kesinlikle Katılıyorum

1.5. Hisse Senedi Piyasalarındaki Anomali Algıları Arasında İlişkiye Yönelik Korelasyon Analizi

Cohen ve diğ. (2003), korelasyon analizinin, iki değişken arasındaki ilişkinin şiddetini ve yönünü ölçmede kullanıldığını ifade etmişlerdir. Araştırmada yapılan faktör analizi sonucu ortaya çıkan boyutlar arası ilişkinin ölçülmesinde korelasyon analizi kullanılmıştır. Korelasyon analizine ilişkin sonuçlar, Tablo 3'te verilmiştir. 
Tablo 3: Hisse Senedi Piyasalarındaki Anomali Algıları Arasında İlişkiye Yönelik Korelasyon Tablosu

\begin{tabular}{|c|c|c|c|c|}
\hline Boyutlar & Firma Anomalisi & Fiyat Anomalisi & $\begin{array}{l}\text { Haftanın Günü } \\
\text { Anomalisi }\end{array}$ & Gün İçi Anomalisi \\
\hline Firma Anomalisi & 1 & & & \\
\hline Fiyat Anomalisi & $\begin{array}{c}, 659\left(^{*}\right) \\
, 000\end{array}$ & 1 & & \\
\hline Haftanın Günü Anomalisi & $\begin{array}{c}, 312\left(^{*}\right) \\
, 000\end{array}$ & $\begin{array}{c}, 358(*) \\
, 000\end{array}$ & 1 & \\
\hline Gün İçi Anomalisi & $\begin{array}{l}, 053 \\
, 264\end{array}$ & $\begin{array}{c}, 124(* *) \\
, 008\end{array}$ & $\begin{array}{c}, 337\left(^{*}\right) \\
, 000\end{array}$ & 1 \\
\hline
\end{tabular}

* Korelasyon 0,01 düzeyinde anlamlı (2 yönlü)

Korelasyon analizinde; korelasyon katsayısının mutlak değer olarak 0-0,30 arasında olması düşük, $0,30-0,70$ arasında olması orta, 0,70 ve üzeri olması yüksek düzeyde bir ilişki olarak tanımlanmaktadır (Büyüköztürk, 2008: 34). Tablo 3'e göre Firma Anomalisi ile Fiyat Anomalisi ve Haftanın Günü Anomalisi arasında orta düzeyde, pozitif ve anlamlı bir ilişki olduğu görülmektedir. Fiyat Anomalisi ile Haftanın Günü Anomalisi arasında pozitif yönlü orta dereceli bir ilişkiye rastlanmıştır. Bunun yanı sıra Fiyat Anomalisi ile Gün İçi Anomalisi arasında pozitif yönlü zayıf derecede bir ilişki tespit edilmiştir. Ayrıca Haftanın Günü Anomalisi ile Gün İçi Anomalisi arasında orta düzeyde pozitif yönlü anlamlı bir ilişki bulunmaktadır.
1.6. Hisse Senedi Piyasalarındaki Anomali Algıları Demografik ve Yatırımcı Özellikleri Arasında Farklılık Analizi

Bireysel yatırımcıların hisse senedi piyasalarındaki anomali algıları ile demografik özellikleri ile yatırımcı özellikleri arasındaki farklılıkların tespit edilmesinde farklııkları incelemeye yönelik parametrik analiz tekniklerinden $\mathrm{t}$ - testi, ve Anova testleri kullanılmıştır. Hisse senedi piyasalarındaki anomali algılarının cinsiyete göre anlamlı bir farklılık gösterip/göstermediğini belirlemeye yönelik olarak yapılan t-testine ilişkin sonuçlar Tablo 4'te sunulmaktadır.

Tablo 4: Cinsiyete Göre hisse senedi piyasalarındaki anomali algılarına İlişkin T-Testi

\begin{tabular}{|c|c|c|c|c|c|c|c|}
\hline \multirow{2}{*}{ Cinsiyet } & \multirow[b]{2}{*}{$\mathrm{F}$} & \multicolumn{2}{|c|}{$\begin{array}{l}\text { Varyansların Eşitliği için } \\
\text { Levene Testi Sonuçları }\end{array}$} & \multicolumn{4}{|c|}{ Ortalamaların Eşitliği İçin T -Testi } \\
\hline & & Sig. & $\mathrm{t}$ & $d f$ & $\mathrm{p}$ & $\begin{array}{c}\text { Ortalama } \\
\text { Farkları }\end{array}$ & \\
\hline \multirow{2}{*}{ Firma Anomalisi } & Varyanslar Eşit & 3,928 & ,048 & 2,196 & 453 & ,029 & , 194 \\
\hline & Varyanslar Eşit Değil & & & 2,146 & 300 & ,033 & 2,146 \\
\hline \multirow{2}{*}{ Gün İçi Anomalisi } & Varyanslar Eşit & ,384 &, 536 & $-2,026$ & 452 & ,043 &,- 185 \\
\hline & Varyanslar Eşit Değil & & & $-1,974$ & 300,504 & ,049 &,- 185 \\
\hline
\end{tabular}

Tablo 4 incelendiğinde, cinsiyete göre firma anomalisi ve gün için anomalisi algısı istatistiksel olarak anlamlı bir farklılık göstermektedir $(p<0,05)$. Bununla beraber fiyat anomalisi ve haftanın günü anomalisi ile cinsiyet arasında istatistiksel olarak anlamlı bir farklılık tespit edilememiştir $(p>0,05)$.

Bireysel yatırımcıların hisse senedi piyasalarındaki anomali algılarının, demografik özelliklerine göre farklılık gösterip göstermediğinin tespit edilmesi için tek yönlü Anova testi yapılmıştır ve elde edilen bulgular Tablo 5'te sunulmuştur.
Tablo 5 incelendiğinde, fiyat anomalisi $(F=3,973$, $p<0,05)$ ve haftanın günü anomalisi $(F=12,392$, $p<0,05)$, bireysel yatırımcıların medeni durumuna göre istatistiksel olarak anlamlı bir farklılık göstermektedir. Firma anomalisi ( $F=3,710, p<0,05)$, haftanın günü anomalisi $(F=5,783, p<0,05)$ ve gün içi anomalisi $(F=4,552, p<0,05)$, bireysel yatırımcıların yaşına göre, Fiyat anomalisi ve Firma anomalisi algısı, katılımcıların eğitim düzeyine ve mesleğine göre farklılık göstermektedir. 
Tablo 5. : Bireysel Yatırımcıların Demografik Özellikleri ile Anomali Algılarına İlişkin Tek Yönlü Anova Testi

\begin{tabular}{|c|c|c|c|c|c|c|c|}
\hline Değ. & Boyutlar & Varyansın Kaynağı & $\begin{array}{l}\text { Kareler } \\
\text { Toplamı }\end{array}$ & df & $\begin{array}{c}\text { Kareler } \\
\text { Ortalaması }\end{array}$ & $\mathrm{F}$ & $\mathrm{P}$ \\
\hline \multirow{2}{*}{$\begin{array}{ll}\bar{c} & \varepsilon \\
\frac{d}{2} & \frac{1}{2} \\
\frac{d}{2} & \end{array}$} & Fiyat Anomalisi & $\begin{array}{c}\text { Gruplar Arası } \\
\text { Grup Içi }\end{array}$ & $\begin{array}{c}5,352 \\
305,111\end{array}$ & $\begin{array}{c}2 \\
453\end{array}$ & $\begin{array}{c}2,676 \\
, 674\end{array}$ & 3,973 & 019 \\
\hline & $\begin{array}{l}\text { Haftanın Günü } \\
\text { Anomalisi }\end{array}$ & $\begin{array}{l}\text { Gruplar Arası } \\
\text { Grup İ̧ci }\end{array}$ & $\begin{array}{c}24,951 \\
456,046\end{array}$ & $\begin{array}{c}2 \\
453\end{array}$ & $\begin{array}{c}12,476 \\
1,007\end{array}$ & 12,392 & 000 \\
\hline \multirow{3}{*}{$\underset{\pi}{\pi}$} & Firma Anomalisi & $\begin{array}{l}\text { Gruplar Arası } \\
\text { Grup İçi }\end{array}$ & $\begin{array}{c}14,840 \\
354,182\end{array}$ & $\begin{array}{c}4 \\
450\end{array}$ & $\begin{array}{c}3,710 \\
, 787\end{array}$ & 4,714 & 001 \\
\hline & $\begin{array}{l}\text { Haftanın Günü } \\
\text { Anomalisi }\end{array}$ & $\begin{array}{l}\text { Gruplar Arası } \\
\text { Grup İ̧ci }\end{array}$ & $\begin{array}{c}23,132 \\
457,866\end{array}$ & $\begin{array}{c}4 \\
451\end{array}$ & $\begin{array}{l}5,783 \\
1,015\end{array}$ & 5,696 & ,000 \\
\hline & Gün İçi Anomalisi & $\begin{array}{l}\text { Gruplar Arası } \\
\text { Grup İ̧ci }\end{array}$ & $\begin{array}{c}18,209 \\
376,438\end{array}$ & $\begin{array}{c}4 \\
449\end{array}$ & $\begin{array}{c}4,552 \\
, 838\end{array}$ & 5,430 & ,000 \\
\hline \multirow{2}{*}{ 占 } & Firma Anomalisi & $\begin{array}{c}\text { Gruplar Arası } \\
\text { Grup İçi }\end{array}$ & $\begin{array}{c}10,789 \\
358,233\end{array}$ & $\begin{array}{c}3 \\
451\end{array}$ & $\begin{array}{c}3,596 \\
, 794\end{array}$ & 4,528 & ,004 \\
\hline & Fiyat Anomalisi & $\begin{array}{l}\text { Gruplar Arası } \\
\text { Grup İçi }\end{array}$ & $\begin{array}{c}19,475 \\
290,988\end{array}$ & $\begin{array}{c}3 \\
452\end{array}$ & $\begin{array}{c}6,492 \\
, 644\end{array}$ & 10,084 & ,000 \\
\hline \multirow{2}{*}{$\frac{\frac{v}{\omega}}{\frac{\tilde{e}}{\Sigma}}$} & Firma Anomalisi & $\begin{array}{l}\text { Gruplar Arası } \\
\text { Grup İ̧ci }\end{array}$ & $\begin{array}{c}34,109 \\
334,913\end{array}$ & $\begin{array}{c}7 \\
447\end{array}$ & $\begin{array}{c}4,873 \\
, 749\end{array}$ & 6,504 & ,000 \\
\hline & Fiyat Anomalisi & $\begin{array}{l}\text { Gruplar Arası } \\
\text { Grup İçi }\end{array}$ & $\begin{array}{c}35,995 \\
274,468\end{array}$ & $\begin{array}{c}7 \\
448\end{array}$ & $\begin{array}{c}5,142 \\
, 613\end{array}$ & 8,393 & 000 \\
\hline
\end{tabular}

Demografik faktörlere ilişkin farklılığın kaynağını bulmaya yönelik yapılan Scheffe testi sonuçlarına göre; Fiyat anomalisi algısı evliler ile bekârlar arasında, haftanın günü anomalisi ise bekârlar ile evliler ve diğer (dul, boşanmış, vb.) arasında farklııı göstermektedir. 18-24 yaş arasındaki katıımcılar ile 45 yaş ve üzeri katılımcılar arasında firma anomalisi algısında farklılık bulunmaktadır. 35-44 yaş arasındaki katıımcılar, 18-24 yaş ve 55 yaş ve üzeri katılımcılar arasında firma anomalisi algısında, 25-34 yaş arasındaki katılımcılar ile de gün içi anomalisi algısında farklılıklar bulunmaktadır. Lisansüstü eğitim almış kişilerin fiyat anomalisi algısı, lise ve lisans mezunu katılımcıların fiyat anomalisi algısından farklııık göstermektedir. Özel sektörde ücretli olarak çalışanlar ile kamuda ücretli olarak çalışanlar, firma anomalisi ve fiyat anomalisi hakkında farklı görüşlere sahiptirler.
Tablo 6 incelendiğinde, yatırımcıların hisse senedi tecrübelerine ve hisse senedini ellerinde bulundurma sürelerine göre fiyat anomalisi, firma anomalisi, haftanın günü anomalisi ve gün içi anomalisi algısı farklılık göstermektedir. bireysel yatırımcıların medeni durumuna göre istatistiksel olarak anlamlı bir farklılık göstermektedir. Firma anomalisi $(F=21,309$, $p<0,05)$ ve fiyat anomalisi algısı $(F=14,410, p<0,05)$, bireysel yatırımcıların ellerinde bulundurdukları hisse senedi sayısına göre farklılık göstermektedir. Hisse senedi portföy değerine göre Firma anomalisi ( $F=$ $48,404, p<0,05)$ ve fiyat anomalisi $(F=51,648, p<0,05)$ ve gün içi anomalisi algısı $(F=3,825, p<0,05)$ arasında istatistiksel olarak anlamlı farklılık bulunmaktadır. Ayrıca menkul kıymet piyasaları hakkındaki bilgi düzeyine göre firma anomalisi, fiyat anomalisi ve haftanın günü anomalisi algısı arasında farklılık bulunduğu ileri sürülebilir. 
Tablo 6. : Yatırımcı Özellikleri ile Anomali Algılarına İlişkin Tek Yönlü Anova Testi

\begin{tabular}{|c|c|c|c|c|c|c|c|}
\hline Değişkenler & Boyutlar & Varyansın Kaynağı & $\begin{array}{l}\text { Kareler } \\
\text { Toplamı }\end{array}$ & df & $\begin{array}{c}\text { Kareler } \\
\text { Ortalaması }\end{array}$ & $\mathbf{F}$ & $\mathbf{P}$ \\
\hline \multirow{4}{*}{$\begin{array}{c}\text { Hisse Senedi } \\
\text { Yatırım } \\
\text { Deneyimi }\end{array}$} & Firma Anomalisi & $\begin{array}{l}\text { Gruplar Arası } \\
\text { Grup İçi }\end{array}$ & $\begin{array}{c}45,486 \\
323,536\end{array}$ & $\begin{array}{c}4 \\
450\end{array}$ & $\begin{array}{c}11,371 \\
, 719\end{array}$ & 15,816 & ,000 \\
\hline & Fiyat Anomalisi & $\begin{array}{l}\text { Gruplar Arası } \\
\text { Grup İçi }\end{array}$ & $\begin{array}{c}50,959 \\
259,504\end{array}$ & $\begin{array}{c}4 \\
451\end{array}$ & $\begin{array}{c}12,740 \\
, 575\end{array}$ & 22,141 & ,000 \\
\hline & Haftanın Günü Anomalisi & $\begin{array}{l}\text { Gruplar Arası } \\
\text { Grup İçi }\end{array}$ & $\begin{array}{c}15,425 \\
465,573\end{array}$ & $\begin{array}{c}4 \\
451\end{array}$ & $\begin{array}{l}3,856 \\
1,032\end{array}$ & 3,736 & ,005 \\
\hline & Gün İçi Anomalisi & $\begin{array}{l}\text { Gruplar Arası } \\
\text { Grup İçi }\end{array}$ & $\begin{array}{c}15,262 \\
379,386\end{array}$ & $\begin{array}{c}4 \\
449\end{array}$ & $\begin{array}{c}3,815 \\
, 845\end{array}$ & 4,5161 & ,001 \\
\hline \multirow{4}{*}{$\begin{array}{l}\text { Hisse Senedini } \\
\text { Elde Tutma } \\
\text { Süresi }\end{array}$} & Firma Anomalisi & $\begin{array}{l}\text { Gruplar Arası } \\
\text { Grup İçi }\end{array}$ & $\begin{array}{c}22,034 \\
343,671\end{array}$ & $\begin{array}{c}5 \\
446\end{array}$ & $\begin{array}{c}4,407 \\
, 771\end{array}$ & 5,719 & ,000 \\
\hline & Fiyat Anomalisi & $\begin{array}{c}\text { Gruplar Arası } \\
\text { Grup İçi }\end{array}$ & $\begin{array}{c}24,692 \\
284,889\end{array}$ & $\begin{array}{c}5 \\
446\end{array}$ & $\begin{array}{c}4,998 \\
, 639\end{array}$ & 7,825 & ,000 \\
\hline & Haftanın Günü Anomalisi & $\begin{array}{l}\text { Gruplar Arası } \\
\text { Grup İçi }\end{array}$ & $\begin{array}{c}13,183 \\
465,484\end{array}$ & $\begin{array}{c}5 \\
446\end{array}$ & $\begin{array}{l}2,637 \\
1,044\end{array}$ & 2,526 & ,029 \\
\hline & Gün İçi Anomalisi & $\begin{array}{l}\text { Gruplar Arası } \\
\text { Grup İçi }\end{array}$ & $\begin{array}{c}33,450 \\
361,003\end{array}$ & $\begin{array}{c}5 \\
446\end{array}$ & $\begin{array}{c}6,690 \\
, 809\end{array}$ & 8,265 & ,000 \\
\hline \multirow{2}{*}{$\begin{array}{l}\text { Elde Bulunan } \\
\text { Hisse Senedi } \\
\text { Sayısı }\end{array}$} & Firma Anomalisi & $\begin{array}{l}\text { Gruplar Arası } \\
\text { Grup İçi }\end{array}$ & $\begin{array}{c}58,833 \\
307,843\end{array}$ & $\begin{array}{c}4 \\
446\end{array}$ & $\begin{array}{c}14,708 \\
, 690\end{array}$ & 21,309 & ,000 \\
\hline & Fiyat Anomalisi & $\begin{array}{l}\text { Gruplar Arası } \\
\text { Grup İçi }\end{array}$ & $\begin{array}{c}35,334 \\
274,007\end{array}$ & $\begin{array}{c}4 \\
447\end{array}$ & $\begin{array}{c}8,833 \\
, 613\end{array}$ & 14,410 & ,000 \\
\hline \multirow{3}{*}{$\begin{array}{l}\text { Hisse Senedi } \\
\text { Portföyü } \\
\text { Yatırım Değeri }\end{array}$} & Firma Anomalisi & $\begin{array}{l}\text { Gruplar Arası } \\
\text { Grup İçi }\end{array}$ & $\begin{array}{c}65,137 \\
303,454\end{array}$ & $\begin{array}{c}2 \\
451\end{array}$ & $\begin{array}{c}32,569 \\
, 673\end{array}$ & 48,404 & ,000 \\
\hline & Fiyat Anomalisi & $\begin{array}{c}\text { Gruplar Arası } \\
\text { Grup İçi }\end{array}$ & $\begin{array}{c}57,700 \\
252,484\end{array}$ & $\begin{array}{c}2 \\
452\end{array}$ & $\begin{array}{c}28,850 \\
, 559\end{array}$ & 51,648 & ,000 \\
\hline & Gün İçi Anomalisi & $\begin{array}{l}\text { Gruplar Arası } \\
\text { Grup İçi }\end{array}$ & $\begin{array}{c}6,596 \\
388,047\end{array}$ & $\begin{array}{c}2 \\
450\end{array}$ & $\begin{array}{c}3,298 \\
, 862\end{array}$ & 3,825 & ,023 \\
\hline \multirow{3}{*}{$\begin{array}{c}\text { Menkul kıymet } \\
\text { piyasaları } \\
\text { hakkındaki } \\
\text { bilgi düzeyi }\end{array}$} & Firma Anomalisi & $\begin{array}{l}\text { Gruplar Arası } \\
\text { Grup İçi }\end{array}$ & $\begin{array}{c}64,142 \\
304,880\end{array}$ & $\begin{array}{c}2 \\
452\end{array}$ & $\begin{array}{c}32,071 \\
, 675\end{array}$ & 47,547 & 000 \\
\hline & Fiyat Anomalisi & $\begin{array}{l}\text { Gruplar Arası } \\
\text { Grup İçi }\end{array}$ & $\begin{array}{c}45,000 \\
265,463\end{array}$ & $\begin{array}{c}2 \\
453\end{array}$ & $\begin{array}{c}22,500 \\
, 586\end{array}$ & 38,395 & 000 \\
\hline & Haftanın Günü Anomalisi & $\begin{array}{c}\text { Gruplar Arası } \\
\text { Grup İçi }\end{array}$ & $\begin{array}{c}6,421 \\
474,577\end{array}$ & $\begin{array}{c}2 \\
453\end{array}$ & $\begin{array}{l}3,210 \\
1,048\end{array}$ & 3,064 & ,048 \\
\hline
\end{tabular}

Demografik faktörlere ilişkin farklılığın kaynağını bulmaya yönelik olarak Scheffe testi yapılmıştır. Test sonuçlarına göre 6 yıldan daha az hisse senedi alımsatım deneyimi yatırımcıların firma anomalisi algısı 7 yıl ve üzeri deneyime sahip olan yatırımcılardan farklılık göstermektedir. Fiyat anomalisi algısında ise 1 yıldan az deneyimi olan yatırımcılar ile 4 yıl ve üzeri deneyime sahip olan yatırımcılar arasında istatistiksel olarak anlamlı farklıık bulunmaktadır. Hisse senedi piyasalarında 1yıl ile 6 yıl arası tecrübeye sahip yatırımcılar gün içi anomalisini, 10 yıl ve üzeri deneyime sahip yatırımcılardan farklı algılamaktadırlar. Bunun- la beraber hisse senedi yatırım deneyimi ile haftanın günü anomalisi arasında anlamlı bir farklılık bulunmasına rağmen, farklılığının hangi gruplar arasında bulunduğu belirlenememiştir.

Hisse senetlerini elde tutma süresine göre anomali algısının hangi gruplar arası farklılık gösterdiği incelendiğinde, 3 aydan kısa süreli yatırım yapan katılımcıların, firma anomalisi ve fiyat anomalisini algısı hisse senetlerini 7 yıldan uzun süre elinde bulunduran yatırımcılar ile, haftanını günü anomalisi ve gün içi anomalisi ise hisse senetlerini 7-11 ay arasında elinde tutan yatırımcılar ile farklılık göstermektedir. 
Üç adet veya daha az hisse senedine sahip olan bireysel yatırımcılar firma anomalisini portföyünde 4 adet veya daha fazla hisse bulunduran yatırımcılardan farklı algılamaktadırlar. Bununla beraber 16 adet ve üzeri hisse senedine sahip yatırımcılar ile elinde 15 adetten az hisse senedi bulunan yatırımcıların fiyat anomalisi algısı farklılık göstermektedir.

Yatırımcılar, yatırım tutarına göre portföy değeri "10.000'ye kadar olan yatırımcılar, "10.001 - "50.000 arasında olan yatırımcılar ve "50.001 ve üzeri olan yatırıma sahip alan yatırımcılar olarak üç gruba ayrılmıştır. Firma anomalisi ve fiyat anomalisi algısı her üç yatırımcı grubuna göre farklılık göstermektedir. Bununla beraber gün içi anomalisi algısında, portföy değeri "10.001 - "50.000 arasında olan yatırımcılar ile "50.001 ve üzeri olan yatırımcılar arasında istatistiksel olarak anlamlı bir farklılık bulunmaktadır.

Menkul kıymet piyasalarındaki bilgi düzeyine sınırlı olan yatırımcılar, orta düzeyde olan yatırımcılar ve ileri düzeyde olan yatırımcıların firma anomalisi ve fiyat anomalisi algısı farklılık göstermektedir. Bununla beraber Menkul kıymet piyasalarındaki bilgi düzeyi ile haftanın günü anomalisi arasında anlamlı bir farklılık bulunmasına rağmen, farklılığının hangi gruplar arasında bulunduğu belirlenememiştir.

\section{SONUÇLAR}

1970'li yıllarda ortaya atılan Etkin Piyasalar Hipotezi (EPH), en genel tanımı ile hisse senedi fiyatlarının her zaman mevcut tüm bilgileri yansıttığını ve yatırımcıların rasyonel davrandığını belirtmektedir. Bu durum, gelecekteki bilginin ve dolayısıyla fiyat değişimlerinin tahmin edilemez olması sonucunu doğurmaktadır. Daha sonra yapılan çalışmalarda, yatıımcıların her zaman rasyonel davran(a)madığını, hisse senedi fiyatlarının belirlenmesinde psikolojik ve davranışsal faktörlerin etkisinin olduğu ve hisse senedi fiyatının kısmen de olsa tahmin edilebileceği görüşü ileri sürülmüş ve etkin piyasalar hipotezinde sapmalar olup olmadığı irdelenmiştir ve etkin piyasalar hipotezinden sapmalar anomali olarak ifade edilmiştir (Malkiel, 2003). Bu çalışmada, bireysel yatırımcıların hisse senedi piyasalarında görülen anomalilere ilişkin görüşlerinin hangi boyutlar altında toplandığının belirlenmesi ve yatırımcıların özellikleri ile anomali algıları arasındaki ilişkinin incelenmesi amaçlanmıştır.

Araştırma sonuçlarına göre bireysel yatırımcılar hisse senedi piyasalarında görülen anomalileri, firma anomalisi, fiyat anomalisi, haftanın günü ve gün içi anomalisi olarak algılamaktadırlar. Literatürde anomaliler, takvim anomalisi, firma anomalisi ve fiyat anomalisi olarak üç başlık altında incelenmektedir. Yatırımcıların anomali algıları Cross (1973), Gibbons ve Hess (1981) ve
Ariel'in (1987) çalışmalarında belirttikleri takvim anomalisi ile, Reinganum (1982), Arbel ve Strabel (1982) ve Merton'un (1987) firma anomalisi ile, De Bondt ve Thale (1985), Jegadeesh ve Titman (1993), Madiha ve diğ. (2011) ve Barak'ın (2008) savundukları fiyat anomalisi ile benzerlik gösterdiği görülmektedir. Bu bağlamda araştırma sonuçlarının literatürle örtüştüğü ileri sürülebilir. Bununla birlikte takvim anomalisinin haftanın günü ve gün içi olarak daha kısa dönemler halinde incelenmesi gerektiği görüşü savunulabilir. Ayrıca takvim dönemi uzadıkça takvim anomalisinin fiyat anomali olarak algılandığı fiyat anomalisinin ise firma anomalisi olarak algılandığı söylenebilir.

Çalışma sonuçlarına göre fiyat anomalisi algısı medeni durum, eğitim ve mesleğe göre, firma anomalisi algısı ise yaş eğitim ve mesleğe göre farklılık göstermektedir. Haftanın günü anomalisi algısında medeni durum ve yaşa göre farklılık görülürken gün içi anomalisi algısında ise yalnızca yaşa göre farklılık bulunmaktadır. Hisse senedi yatırımlarının riskli yatırımlar olması ve finansal risk algısının demografik özelliklere göre farklılık göstermesi (Saraç ve Kahyaoğlu, 2011) yatırımcıları anomali algısının farklılı̆ının nedeni olarak gösterilebilir.

Çalışma sonucunda, firma, fiyat, haftanın günü ve gün içi anomalileri algıları ile hisse senedi yatırım deneyimi ve hisse senedini elinde bulundurma süresi arasında anlamlı farklılıklar bulunmuştur. Ayrıca fiyat anomalisi algısı ile firma anomalisi algısı, yatırımcının sahip olduğu hisse senedi sayısına, portföy değerine ve menkul kıymet piyasaları hakkındaki bilgi düzeyine göre farklılık göstermektedir. Haftanın günü anomalisi algısında menkul kıymet piyasaları hakkındaki bilgi düzeyine göre farklılık görülürken gün içi anomalisi algısında ise portföy değerine göre farklılık bulunmaktadır. Diğer bir ifade ile hisse senedi piyasalarında deneyimi az olan yatırımcılar ile deneyimli yatırımcıların, kısa süreli yatırımcılar ile uzun dönemli yatırımcıların, sınırlı bilgiye sahip yatırımcılar ile ileri düzey bilgi sahibi yatırımcıların anomali algısı farklık göstermektedir. Ayrıca elinde az sayıda hisse bulunduran yatırımcılar ile çok sayıda hisse senedi bulunduran yatırımcıların, portföy değeri düşük olan yatırımcılar ile portföy değeri orta ve yüksek olan yatırımcıların anomali algıları arasında farklılık bulunmaktadır. Bu farklılıkların bilişsel çelişki, pişman olma gibi duygusal faktörlerden ve/veya inançta ısrarcılık, zaman değişkenli tercihler, optimizm, aşina olma, aşırı güven vb. bilişsel önyargılardan kaynaklandığı öne sürülebilir.

Çalışma sonucunda elde edilen bulgular ve kullanılan ölçekler bu alanda yapılacak çalışmalara katkı sağlayacaktır. İlerde yapılacak çalışmalar için araştırmacılara, farklı hisse senedi piyasalarında işlem yapılan yatırımcıları kapsayan araştırmalar yapılması önerilebilir. 


\section{KAYNAKÇA}

Abdioğlu, Z. ve Değirmenci, N. (2013) "İstanbul Menkul Kıymetler Borsasında Mevsimsel Anomaliler” Business and Economics Research Journal, 4 (3): 55-73.

Agrawal, A. ve Tandon, K. (1994) "Anomalies or İllusions? Evidence from Stock Markets in Eighteen Countries" Journal of International Money and Finance, 13: 83-106.

Altunışık, R., Çoşkun, R., Bayraktaroğlu, S. ve Yıldırım, E. (2007) Sosyal Bilimlerde Araştırma Yöntemleri SPSS Uygulamal, Sakarya, Sakarya Yayıncilı.

Ariel, R.A. (1987) "A Monthly Effect in Stock Returns" Journal of Financial Economics, 18: 161-174.

Balaban, E. (1995) "Day of the week effects: new evidence from an emerging stock market" Applied Economics Letters, 2: 139-43.

Balbina, M. ve Martins, N.C. (2002) "The Analysis of Seasonal Return Anomalies in the Portuguese Stock Market” Banco de Portugal Working papers, 11 (02).

Barak O. (2006) "Hisse Senedi Piyasalarında Anomaliler ve Bunları Açıklamak Üzere Geliştirilen Davranışsal Finans Modelleri -İMKB'de Bir Uygulama” Yayımlanmamış Doktora Tezi, Ankara, Gazi Üniversitesi Sosyal Bilimler Enstitüsü.

Barak, O. (2008) “İmkb’de Aşırı Reaksiyon Anomalisi ve Davranışsal Finans Modelleri Kapsamında Değerlendirilmesi" Gazi Üniversitesi İktisadi ve İdari Bilimler Fakültesi Dergisi, 10 (1): 207 - 229.

Barak, O. (2008) Davranıssal Finans -Teori ve Uygulama, Ankara, Gazi Kitabevi.

Bayar, A. ve Kan Ö.B. (2002) "Day of the Week Effects: Recent Evidence from Nineteen Stock Markets" TCMB Araştırma Yayınları, Central Bank Review, 2: 77 90

Bildik, R. (2000) Hisse Senedi Piyasalarında Dönemsellikler ve IMKB Üzerine Ampirik Bir Çalışma, İstanbul, İMKB Yayınları.

Büyüköztürk, Ş. (2008) Sosyal Bilimler İçin Veri Analizi El Kitabı, 9. Baskı, Ankara, Pegem Akademi.

Cohen, J., Cohen P., West G. S. ve Aiken, L. S. (2003) Applied Multiple Regression / Correlation Analysis for the Behavioral Sciences, 3rd Editon, New Jersey: Lawrence Erlbaum Associates.

Cross, F. (1973) "The Behavior of Stock Prices on Friday and Mondays" Financial Analysts Journal, 29: 67-69.

De Bondt W.F.M. ve Thaler, R. (1985) "Does the Stock Market Overreact?" Journal of Finance, 40: 793805.
Demir, A., Küçükkiremitçi, O., Pekkaya, S. ve Üreten, A (1996) "Fiyat/Kazanç Oranına ve Firma Büyüklüğüne Göre Oluşturulan Portföylerin Performanslarının Değerlendirilmesi (1990-1996 Dönemi İçin İMKB Uygulaması)" Sermaye Piyasası ve İMKB Üzerine Çalışmalar, 39-69

Ege,İ., Topaloğlu, E.E. ve Coşkun, D. (2012) “Davranıssal Finans ve Anomaliler: Ocak Ayı Anomalisinin İMKB'de Test Edilmesi" Muhasebe ve Finansman Dergisi, Ekim sayısı: 176-190.

Erdoğan, M. ve Elmas, B. (2010) "Hisse Senedi Piyasalarında Görülen Anomaliler ve Bireysel Yatırımcı Üzerine Bir Araştırma” Atatürk Üniversitesi Sosyal Bilimler Enstitüsü Dergisi, 14 (2): 1-22.

French, K. R. (1980) "Stock returns and the weekend effect” Journal of Financial Economics, 8: 55-69.

Ergün, B. (2009) "Piyasa Anomalileri ve Aşırı Tepki Hipotezinin İMKB'de Araştırılması” Yayımlanmamış Yüksek Lisans Tezi, Adana, Çukurova Üniversitesi Sosyal Bilimler Enstitüsü.

Gibbons, M. and Hess, P. (1981) "Day of the Week Effects and Asset Returns" Journal of Business, 54: 579596.

Guo, S. ve Wang, Z. (2007) "Market efficiency anomalies: A study of seasonality effect on the Chinese stock Exchange", Yayımlanmamış Yüksek Lisans Tezi, Umeå University Umeå School of Business

Jaffe, J. ve Westerfield, R. (1985) "The Weekend Effect in Common Stock Returns: The International Evidence" Journal of Finance, 40 (2): 433-454.

Jegadeesh, N. ve Titman, S. (1993) "Returns to buying winners and selling losers: implications for stock market efficiency" Journal of Finance 48: 65-91.

Kahneman, D., Knetsch, J.L. ve Thaler, R.H. (1991) "Anomalies: The Endowment Effect, Loss Aversion, and Status Quo Bias" The Journal of Economic Perspectives, 5 (1): 193-206

Karan, M. B. (2001) "İstanbul Menkul Kiymetler Borsası Anomalileri” Ege Akademik Bakış Dergisi, 1 (2): 280-281.

Madiha L., Shanza A., Mariam F. ve Samia F. (2011) "Market Efficiency, Market Anomalies, Causes, Evidences, and Some Behavioral Aspects of Market Anomalies" Research Journal of Finance and Accounting, 2 (9/10): $1-14$.

Malkiel B.G. (2012) "Stock Market Price Behaviour" Wiley Online Library, 25 (2): 383-417

Malkiel, B.G. (2003) “The Effcient Market Hypothesis and Its Critics" Journal of Economic Perspectives, 17 (1): $59-82$. 
Nawaz, S. ve Mirza, N. (2012) "Calendar Anomalies and Stock Returns: A Literature Survey" Journal of Basic and Applied Scientific Research, 2 (12): 12321-12329

Nunnally, J. C. (1967) Psychometric Theory, New York, MacGraw-Hill Book Company.

Özmen, T. (1997) Dünya borsalarında gözlemlenen anomaliler ve İstanbul menkul kıymetler borsası üzerine bir deneme, Ankara,Sermaye Piyasası Kurulu Yayınları.

Pompian, M.M. (2006) Behavioral Finance and Wealth Management, New Jersey, John Wiley \& Sons, Inc.

Reinganum, M.R. (1982) "A Direct Test of Roll's Conjecture on the Firm Size Effect" Journal of Finance, 37 (1): 27-35.

Rogalski, R. (1984) "New Findings Regarding Dayof-the-Week Returns over Trading and Non-Trading Periods: A Note” Journal of Finance, 39: 1603-1614.

Saraç, M. ve Kahyaoğlu M.B. (2011) Bireysel Yat1rımcıların Risk Alma Eğilimine Etki Eden Sosyo-Ekonomik ve Demografik Faktörlerin Analizi, BDDK Bankacılik ve Finansal Piyasalar Dergisi, 5 (2): 135-157.
Shiller, R.J. (1998) "Human Behavior and the Efficiency of the Financial System" Yale University Working Paper, 1-28.

Tunçel, A.K. (2008) "Haftanın Günü Etkisine Yeni Bir Yaklaşım: İMKB Örneği” Trakya Üniversitesi, Sosyal Bilimler Dergisi, 10 (2): 246-271.

Tunçel, A.K. (2012) "İstanbul Menkul Kıymet Borsasında Yılın Ayı Etkisi” Yönetim Bilimleri Dergisi, 10 (19): 1-30

TÜYİD ve MKK(2014) Borsa Trendleri Raporu, Say1 7: Ocak -Aralık 2013, 20 Ocak 2014, https:// www.mkk.com.tr/wps/wcm/connect/3dca7533-e85045f4-8796 8d35aefdf632/BIST_ Trendleri_Raporu_VII. pdf?MOD=AJPERES, $(13.05 .2014)$ 